\title{
Web Information System for the Governance of University Research
}

\author{
Khaoula Benmoussa \\ Information System Engineering Research Group \\ National School of Applied Sciences \\ Abdelmalek Essaadi University \\ Tetouan, Morocco \\ Majida Laaziri \\ Information System Engineering Research Group \\ National School of Applied Sciences \\ Abdelmalek Essaadi University \\ Tetouan, Morocco
}

\author{
Samira Khoulji \\ Information System Engineering Research Group \\ National School of Applied Sciences \\ Abdelmalek Essaadi University \\ Tetouan, Morocco \\ Kerkeb Mohamed Larbi \\ Information System Engineering Research Group \\ Faculty of Sciences \\ Abdelmalek Essaadi University \\ Tetouan, Morocco
}

\begin{abstract}
Technology development has proved crucial in analyzing and processing the volume of scientific information that is generated today. Governments are developing scientific and technical information systems that, beyond a database, are a real tool for supporting research management and decisionmaking in the field of science and technology policy. For the development of higher education in Morocco, the ministry has focused on projects for the management and development of university research. For this purpose, Abdelmalek Essaadi University developed an efficient application dedicated to the management of collaborative extranet called SIMarech (Moroccan Information System of Scientific Research), in order to support, organize and structure all academic activities. It will enable all university stakeholders to use a digital workspace specific to their roles, to access and share information, and interact and engage in national scientific research. This article presents an overview of research management systems and the design and development of SIMarech, which is designed as a tool for monitoring research conducted by a university or other institutions.
\end{abstract}

Keywords-SIMarech platform; web information system; management of research; university scientific research

\section{INTRODUCTION}

Governments want high-level universities because the modern economy is based on scientific research and highly skilled human capital. Each university must have a clear and evidence-based understanding of the institution's research performance in relation to its objectives and mission [1]. Since research is a central function, the university must evaluate its research performance, something that will help the decision making about which research areas to support or build [2]. It will also help university leaders to understand the institution's position in relation to global and national standards of research production. For a good piloting of scientific research, an information system becomes a mandatory condition to manage better investments in science in order to evaluate the performance of research and to establish a solid policy for the development of scientific research [3]. To this end, Moroccan universities have decided to adopt the digital application called SIMarech set up by Abdelmalek Essaadi University, which aims to develop an information system initiative whose ultimate goal is to support researchers and enhance their scientific activities. The incorporation of SIMarech into Moroccan universities has contributed to a significant increase in the number of active researchers, the quantity of research projects in progress, the external and internal funds obtained and the number of publications in indexed journals. SIMarech can be defined as a set of people, processes and equipment designed, built, operated and maintained to collect, record, process, store, retrieve and display information about the activities and results produced by the researchers in their development centers or in collaboration with other national or international institutions.

\section{GLOBAL RESEARCH MANAGEMENT SYSTEMS OVERVIEW}

Global research management has benefited greatly from the development of research management systems that reflect the research results generated in universities and research centers, organizations, institutions, etc. The development or improvement of a research information system requires a comparative study of similar existing systems and as well as taking into account remarks from researchers or users of the system.

\section{A. Research Management Systems in Latin America}

Table I shows an overview, the advantages and the disadvantages of the respected systems (SGI, SICyTAR).

\section{B. Research Management Systems in Europe}

The same applies in Table II regarding the European research management systems (SICA, GRAAL, IRIS). 
TABLE I. LATIN AMERICAN RESEARCH MANAGEMENT SYSTEMS

\begin{tabular}{|c|c|c|c|}
\hline Systems & Overview & $\begin{array}{l}\text { Advantages } \\
\end{array}$ & Cons \\
\hline SGI (Chile) & $\begin{array}{l}\text { Developed in } 2001 \text { at } \\
\text { the University of Talca } \\
\text { to support the academic } \\
\text { activities of their } \\
\text { researchers [4]. }\end{array}$ & $\begin{array}{c}\text { - Includes a range of information services for the exclusive use of } \\
\text { specific users of university researchers, } \\
\text { - Aims to have a set of indicators and related statistics of available } \\
\text { research capabilities, } \\
\text { - Stays informed in the results of academic research, } \\
\text { - Exchange knowledge at national and international level, } \\
\text { - Allows visitors to the SGI platform to view the researchers' CV [4-6]. }\end{array}$ & $\begin{array}{l}\text { - Limited to the management of } \\
\text { university research. } \\
\text { - Limited to the management of } \\
\text { research projects and indexed } \\
\text { publications. [4] }\end{array}$ \\
\hline $\begin{array}{c}\text { SICyTAR } \\
\text { (Argentina) }\end{array}$ & $\begin{array}{l}\text { SICyTAR was } \\
\text { established in 2002, in } \\
\text { order to facilitate and } \\
\text { unify the access to } \\
\text { information on } \\
\text { scientists, technicians } \\
\text { and their jobs [11]. }\end{array}$ & $\begin{array}{l}\text { - Keeps a unified CVar register constantly updated [9]. } \\
\text { - Produces through the InfoSICYTAR service of the platform detailed } \\
\text { statistical information to develop indicators and evaluate science and } \\
\text { technology policies, for exclusive use by the institutions of National } \\
\text { System of Science, Technology and Innovation [10] } \\
\text { - Provides the BUSCAR tool for networking among researchers, as well } \\
\text { as government and commercial sectors accessible to all visitors [7]. }\end{array}$ & $\begin{array}{l}\text { - There is not an identifier to } \\
\text { distinguish the user from the system, } \\
\text { - It is accessible to everyone, a } \\
\text { researcher or other from any country } \\
\text { can create an account and provide } \\
\text { false information, something that } \\
\text { makes the statistics information } \\
\text { withheld questionable [8]. }\end{array}$ \\
\hline
\end{tabular}

TABLE II. EUROPEAN RESEARCH MANAGEMENT SYSTEMS

\begin{tabular}{|c|c|c|c|}
\hline Systems & Overview & Advantages & Cons \\
\hline $\begin{array}{c}\text { SICA } \\
\text { (Spain) }\end{array}$ & $\begin{array}{l}\text { SICA was born as a research project } \\
\text { in } 2001 \text {, through a cooperation } \\
\text { agreement between the Ministry of } \\
\text { Education and Culture of the } \\
\text { Government of Andalusia and the } \\
\text { University of Granada to meet the } \\
\text { specific needs of the organizations } \\
\text { of Operational management to } \\
\text { promote research and technological } \\
\text { development in Spain }[13,15] \text {. }\end{array}$ & $\begin{array}{l}\text { - Assists management in general and those responsible for science } \\
\text { policy especially in decision-making, } \\
\text { - Provides updated information from individual researcher programs, } \\
\text { flexible mechanisms for management and maintenance on an ongoing } \\
\text { basis, } \\
\text { - Establishes an authorized knowledge base with standardized criteria } \\
\text { in the evaluation and quality of the results of the scientific activity, } \\
\text { - Encourages the transfer of results between different types of } \\
\text { information }[13,15] \text {. }\end{array}$ & $\begin{array}{l}\text { Accessible to everyone, all } \\
\text { people (researchers or } \\
\text { other) have the } \\
\text { opportunity to create an } \\
\text { account and enrich the } \\
\text { SICA database with } \\
\text { information which may be } \\
\text { wrong [12, 13]. The } \\
\text { evaluation of research by } \\
\text { this system is imprecise. }\end{array}$ \\
\hline $\begin{array}{l}\text { GRAAL } \\
\text { (France) }\end{array}$ & $\begin{array}{l}\text { GRAAL is a software program } \\
\text { launched in } 2000 \text { by the } \\
\text { Interuniversity Computing Center of } \\
\text { Grenoble. Its management was then } \\
\text { entrusted to a group of scientific } \\
\text { interest (GlS) bringing together the } \\
\text { public partners concerned [16]. }\end{array}$ & $\begin{array}{c}\text { - Presents and manages in a coherent way the research units within the } \\
\text { university including the personnel and their scientific activities, } \\
\text { - Manages the monitoring of financial means and international } \\
\text { activities within the university [16]. }\end{array}$ & $\begin{array}{l}\text { Limited just to the } \\
\text { research management of } \\
\text { university research units } \\
{[16] .}\end{array}$ \\
\hline IRIS (Italy) & $\begin{array}{l}\text { Adopted in } 2015 \text { by the University } \\
\text { of L'Aquila in Italy, it is a platform } \\
\text { of data management on research } \\
\text { activities, was designed to meet the } \\
\text { needs of academic institutions and } \\
\text { research. It is now installed in seven } \\
\text { establishments outside Italy [17]. }\end{array}$ & $\begin{array}{l}\text { - IRIS aims to collect, manage and store the results of the scientific } \\
\text { research of the University, } \\
\text { - Professors, researchers, the fellows of research, specialization and } \\
\text { PhD students, as well as administrative staff members can access the } \\
\text { platform using their credentials to catalog their published research, } \\
\text { - IRIS aims to control the results of research and to improve the } \\
\text { visibility of the University's production, } \\
\text { - Has five different modules integrated through standard protocols and } \\
\text { interfaces, } \\
\text { - One of the main components of IRIS is DSpace-CRIS, an open source } \\
\text { solution that can also be used as a standalone system }[17,19] \text {. }\end{array}$ & $\begin{array}{l}\text { Does not allow managing } \\
\text { and evaluating of research } \\
\text { activities of each unit } \\
\text { independently of the other } \\
{[20] \text {. }}\end{array}$ \\
\hline
\end{tabular}

\section{The Globally Recognized Research Information} Management System (RIMS)

RIMS project is an initiative funded by DST and powered by InfoEd. Authors in [21, 22] described RIMS as a potential new category of services for libraries. RIMS is an integrated online system for managing grants and the administration of ethics in research projects and research activities. It provides researchers, administrative and executive staff with a single point of reference for these aspects of research projects [22, 24]. The software is used by more than 600 academic, medical and scientific institutions around the world [21, 22, 24, 25].

\section{SIMARECH}

The Moroccan information system of scientific research (SIMarech) aims to collect, manage and store research (research, professional, educational and international activities) at national level. Its modular nature and flexibility of its data model facilitate the processing, organizing and transmission of information in accordance with international standards. The development team has worked to develop a scalable and customizable application that aligns with local, national and international research policies, and recognizes the autonomy of universities in terms of governance of the scientific research [25]. SIMarech has taken into consideration the advantages and disadvantages of the previously presented systems.

\section{A. General}

SIMarech was created at Abdelmalek Essaadi University in 2008 to help develop the research potential by highlighting the scientific production and know-how of researchers. SIMarech can also be used as an assessment tool and could help decision making. Initially, the system was structured to include a range of services for the exclusive use of specific users based on their 
profile, with respect to programs, projects, events and products resulting from the research activities developed. At the strategic level the system aims to have a set of indicators and related statistics of available research capabilities. SIMarech has been designed to meet the specific needs of universities and Moroccan management bodies, aims to present in a coherent way the institutions and the research units of the university, including the personnel and their scientific activities (Figure 1) and the monitoring of financial resources and international activities [26]. SIMarech provides a description of the existing situation and a needs study for better optimization of human and material resources. It also allows a quantitative national evaluation of research that would provide objective criteria for self-evaluation and external peer review. It is configurable and allows for a transcendent role assignment: teacher-researcher, responsible of a research structure, educational institution and university administrator. Its reporting system makes it possible to print documents, graphs and statistics on various specific sections: indexed publications, communications, projects, patents, etc. [27].

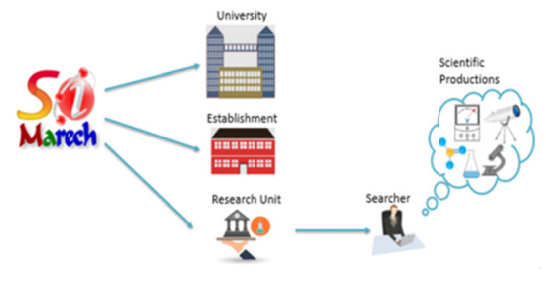

Fig. 1. Generality of SIMarech

1) Administrative Processes

SIMarech is supporting research by providing and maintaining innovative and integrated systems that simplify administrative processes by (Figure 2):

- Reducing the administrative burden.

- Streamlining and automating the administration of research.

- Providing authorized individuals and systems with timely access to information about proposals, rewards and compliance.

- Improving the efficiency of the administration to meet the demands of a growing workload with limited resources.

- Making the research steering process timelier, easier to understand and improving the efficiency of the surrounding processes.

- Making the process more transparent by reporting research status, information sharing and easy integration of data between university management systems.

2) University Process

SIMarech has been designed to meet the specific needs of universities and government by allowing to (Figure 3):

- Promote and increase visibility, exchange and communication between scientists and researchers at regional, national or international level.
- Organize and maintain unified scientific and technological registries to produce accurate, reliable and up-to-date statistics in real time.

- Assist in the overall management of researchers in the institutions research units and their scientific results.

- Consistently present research units and their environment.

- Provide up-to-date information on individual research programs.

- National and international knowledge exchange to enrich the cultural and professional experience of researchers.

- Ensure interoperability between national science and technology databases.

- It offers the opportunity to conduct and participate in institutional appeals, including project funding, by using the information in the $\mathrm{CV}$ and preventing the researcher from resubmitting his $\mathrm{CV}$ in call forms and databases.

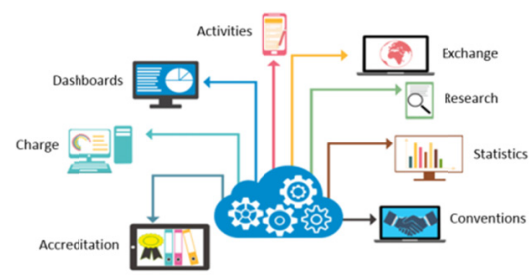

Fig. 2. Administrative process

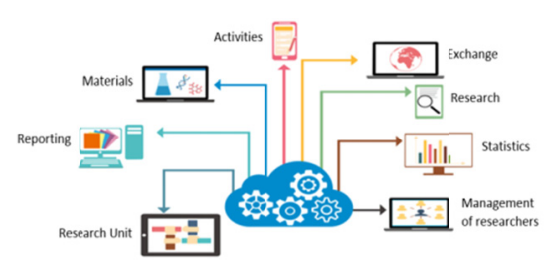

Fig. 3. University processes

\section{B. Object-Oriented Methodology (OOM)}

$\mathrm{OOM}$ is a methodology for object-oriented (OO) development and graphical notation to represent $\mathrm{OO}$ concepts. With this methodology, a computer system can be developed on a component basis that enables the efficient reuse of existing components and facilitates the sharing of its components by other systems. With the adoption of OOM, higher productivity, lower maintenance costs and better quality can be achieved. In other words, object modeling is based on the identification of objects in a system and their interrelationships. Once done, the system coding is complete. There are many OOMs used to develop OO systems [28-30]. In this work, the object modeling technique (OMT) is used because OMT [29] is one of the most used OO design methodologies in the world. It includes the following steps:

1) System Analysis

System analysis is the first phase of development in the case of OMT as in any other system development model. It is a 
concise and precise abstraction of what the desired system must do, not how it will be done. It should not contain any implementation details. The model objects must be application domain concepts and not IT implementation concepts. In this phase, the developer interacts with the system user to know the user's needs and analyzes the system to understand the operation. In system development, analysis is the process of studying and defining the problem to be solved [31, 32].

\section{2) System Design}

The designer makes high-level decisions on the overall architecture. It involves developing an $\mathrm{OO}$ model of a software system to implement the identified requirements. The objects in an $\mathrm{OO}$ design are related to the solution to the problem being solved [33]. In the system design, the target system is organized into various subsystems based on both analysis structure and proposed architecture. If analysis means defining the problem, design is the process of defining the solution. It is a question of defining the ways in which the system satisfies the requirements identified during the analysis.

\section{3) Object Design}

Object design is the process of defining components, interfaces, objects, classes, attributes, and operations that meet the requirements. The designer creates a design model based on the analysis model but containing implementation details. The object of object design is the data structures and algorithms needed to implement each cycle [32]. In large systems, design usually occurs at two scales: the architectural design, the definition of the components from which the system is composed, and designing components, defining classes and interfaces within a component. The important concept in understanding $\mathrm{OO}$ development is based on objects that are grouped into classes.

\section{4) Implementation with Object-Oriented Programming (OOP)}

Class objects and relationships developed in the design of the object are ultimately translated into a particular programming language, database, or hardware implementation [32].

\section{5) Testing}

The completed part of the system is tested from a functional point of view [34]. In other words, testing is continuously interwoven into the development process. This not only locates faults early, it makes subsequent phases less likely to create new faults based on existing ones.

\section{Object-Oriented Analysis and Design (OOAD) with a Unified Modeling Language (UML)}

The perspective of OOAD was to avoid the problem that systems develop: they tend to be very difficult to maintain as the system develops and requirements change. The results of the OOAD phases are captured using a formal syntax of a modeling language, producing an unambiguous model of the system to be implemented [34, 35]. The Unified Modeling Language (UML) was developed to simplify and consolidate the large number of object-oriented development methods, and the Object Management Group (OMG) adopted it as a standard notation. UML is suitable for modeling, ranging from enterprise computing to distributed web applications and even real-time embedded systems [36].

\section{System Architecture Design}

The architecture of an information system defines that system in terms of components and interactions among those components, from the viewpoint of specific aspects of that system, and based on specific structuring principles [36, 37]. This architecture will provide an overview of the design features and development of SIMarech. The structure of the platform is organized into three layers that communicate with each other (Figure 4): A data management layer: the server with a database system and search engine. A layer for interfacing: Framework and API used in system development. A layer for services: SIMarech platform.

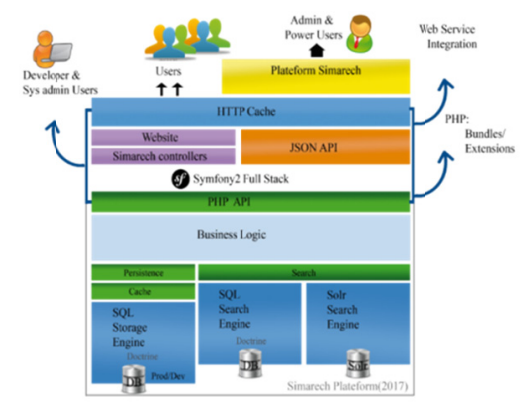

Fig. 4. SIMarech layer architecture

Advantages of using symfony [39] for the development of SIMarech:

- The symfony framework provides consistency in the code and saves time, since several developers manage the SIMarech 3.0 platform at the same time.

- Thanks to the symfony framework we can hand over the updated project to the universities, which allows us to produce or improve versions of SIMarech 3.x.

- It guarantees the separation of the logic of the views by using MVC models [38]. This is a practice that helps keeping the code clean while it facilitates changes.

\section{E. Results}

The SIMarech platform has four spaces: teacher-researcher, responsible of a research structure, dean, university president, each with different access. The spaces of the SIMarech platform for each actor and their functional structure are:

\section{1) Teacher-Researcher Space}

SIMarech offers an account for each teacher-researcher of Moroccan universities (Figure 5), which allows entering personal information, scientific productions, and communication with other teacher-researchers etc. Some characteristics of the teacher-researcher space are:

- Better visibility on each teacher-researcher at national level, university, institution, research structure.

- SIMarech encourages the teacher-researcher to share his scientific activities. 
- It encourages managing and sharing scientific products.

- The teacher-researcher participates in the enrichment of the system base.

- It promotes interactions with teacher-researchers or research structures.

- The teacher-researcher participates in the evaluation of research activities within a research structure.

- It establishes exchanges of information, documentation and scientific cooperation with national and foreign institutes, centers and similar research bodies.

- The teacher-researcher follows and develops the activities of a research unit he belongs to.

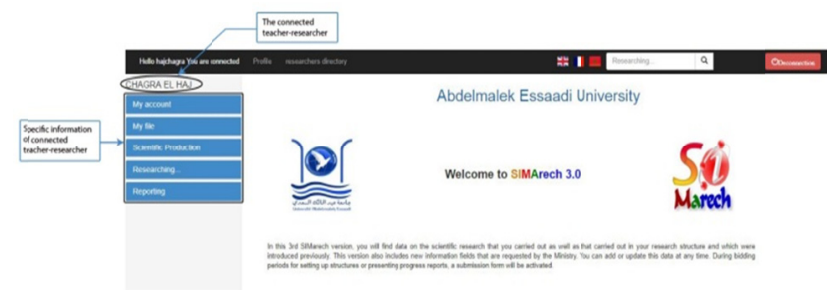

Fig. 5. Teacher-researcher space [40]

\section{2) Space Responsible of a Research Structure}

SIMarech offers an account for the head of a research structure within an institution (Figure 6), who is defined as a pilot and validates the research work of his structure, takes an active part in all the research work. It then occupies a mixed role between his responsibilities of structure and his work as a researcher. SIMarech allows for the responsible of a research structure to:

\section{a) Define research priorities}

- Propose and set up the annual and multi-year research work, in connection with the studies, research and development department.

- Analyze the costs, budgets and schedules necessary for the successful achievement of the research objectives.

- Identify possible improvements in research processes to optimize structure performance. Translate improvement goals into research programs.

- Write and/or validate and print the files needed to obtain funding.

- Exchange information regularly with researchers.

b) Manage internal and external communication on works of the structure

- Validate the different scientific publications of researchers.

- Participate in scientific events: congresses, symposia, round tables, think tanks etc.

- Respond to internal and external solicitations on the work of the structure: balance sheets with the institution or university, meetings with other services etc.
- Animate the partnership policy: links with units, teams, private or public laboratories, with organizations promoting research etc.

\section{c) Coach teams/researchers}

- Validate with them the successes and encountered obstacles and arbitrate on solutions to put in place.

- Individually and collectively assess the performance of the unit's team and ensure the development of skills of researchers.

- Follow the budget and schedules.

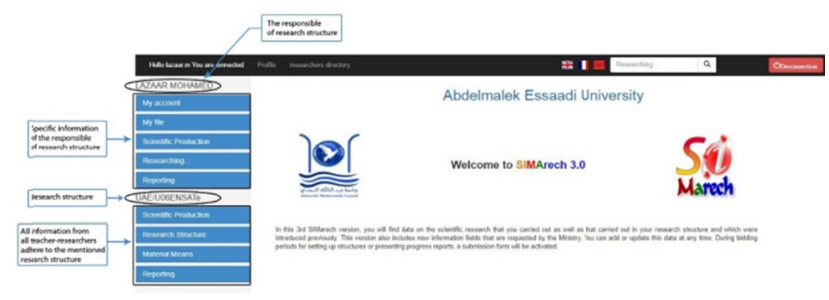

Fig. 6. Space for the responsible of a research structure [40]

3) Dean's space

SIMarech offers an account for all the deans of the establishments (Figure 7), which is defined like pilot and validates the research of all the research structures of his establishment and takes an active part in the research works. It occupies a mixed role between his institutional responsibilities and his work as a researcher. SIMarech allows the dean:

- To provide general communication and information exchange between an institution and the University and more specifically the communication of the work and decisions of the research units.

- To validate the need for means/resources.

- To administer the institution's daily budget.

- To prepare budget forecasts.

- To download the annual report of institution activities.

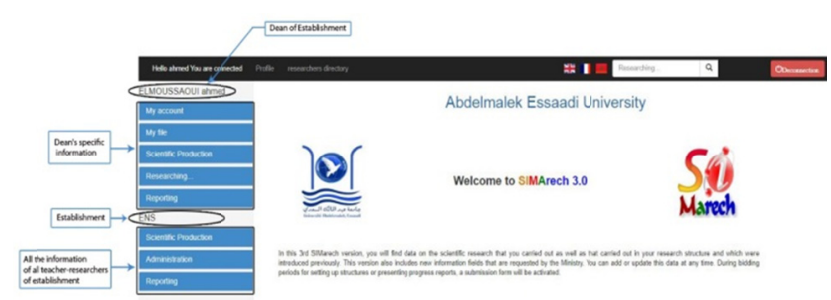

Fig. 7. Dean's space [40]

\section{4) Administrator Space}

SIMarech offers an account for each president of each university (Figure 8) who is defined as the university's CEO, ensures the operational management of the university, supervises institutions, research units, teacher-researchers, manages and validates the works of research of all the institutions of the university and takes an active part in the research work. The CEO occupies a mixed role between the 
presidency of his university and his work as a researcher. The space allows the CEO to meet the needs of institutions, create and manage structures and evaluate the research of the university. SIMarech allows the CEO:

- To check, verify, validate and accredit information etc.

- To ensure the proper functioning of existing units and research and experimental centers and propose the creation or the suppression of a unit, in accordance with the university's scientific policy.

- To publicize and publish the teaching and research results.

- To develop the dissemination of all information and documents to promote the reputation of the university nationally and internationally.

- To manage the income and the expenses of the University.

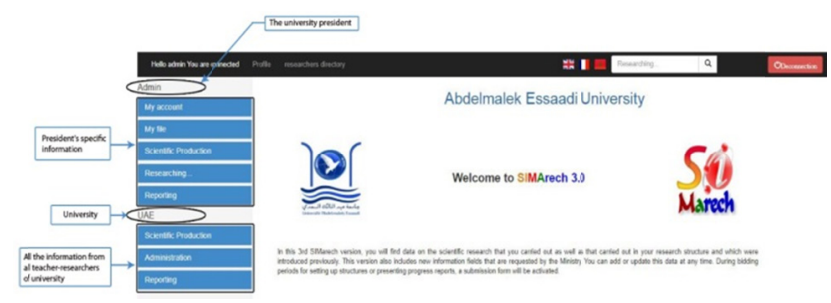

Fig. 8. Administrator's space [40]

\section{CONCLUSION}

The research management in Morocco has been largely benefited by the development of SIMarech which reflects the results of the research generated in Moroccan universities and research centers. SIMarech is an excellent collaborative tool that keeps track of all activities over time, to release on one hand dashboards and statistics reflecting the situation at a given moment and on the other to also characterize the trends of developments and directions taken over time, to evaluate the research performance and monitoring of academic research units as well as to build a dynamic vision of a university's research activities. However, it was above all the interest and efforts of the managers, researchers and evaluators who, with their daily work, made SIMarech a powerful tool, a reference in the current knowledge system and, in the end, a pioneer of experience in Morocco.

\section{ACKNOWLEDGMENT}

This work was supported in part by the Ministry of Higher Education, Scientific Research and Management Training to support national projects in the management of scientific research.

\section{REFERENCES}

[1] G. I. Petrova, V. M. Smokotin, A. A. Kornienko, I. A. Ershova, N. A Kachalov, "Knowledge Management as a Strategy for the Administration of Education in the Research University", Procedia Social and Behavioral Sciences, Vol. 166, pp. 451-455, 2015

[2] A. F. J. Van Raan, "Performance-related differences of bibliometric statistical properties of research groups: Cumulative advantages and hierarchically layered networks", Journal of the American Society for Information Science and Technology, Vol. 57, No. 14, pp. 1919-1935, 2006
[3] N. Barts, Infocentre recherche: système d'information, outil d'aide au pilotage de la recherche d'un établissement de recherche, $\mathrm{PhD}$ Thesis, Université Paul Cézanne-Aix-Marseille III, 2008 (in French)

[4] I. F. Palomo, C. G. Veloso, R. F. Schmal, "Sistema de Gestión de la Investigación en la Universidad de Talca, Chile", Información Tecnológica, Vol. 18, No. 1, pp. 97-106, 2007 (in Spanish)

[5] Universidad de Talca, Informe Gestion Universidad de Talca, 2014 (in Spanish)

[6] J. E. P. Latour, Implementacion de un sistema informatico de gestión de la investigación tecnologica en el I.S.T.P. Carlos Salazar Romero del distrito de Nuevo Chimbote, 2014, Universidat, Catolica Los Angeles Chimbote, 2014 (in Spanish)

[7] Buscador SICYTAR, available at: http://sicytar.mincyt.gob.ar/buscar/\#/, (in Spanish)

[8] SICYTAR Identificación de Usuario, available at: http://cvar.sicytar.mincyt.gob.ar/auth/index.jsp (in Spanish)

[9] CVar, available at: http://www.mincyt.gob.ar/accion/cvar-6467 (in Spanish)

[10] Nuevo sitio del Sistema de Información de Ciencia y Tecnología Argentino - Ministerio de Ciencia, Tecnología e Innovacion Productiva, available at: http://www.mincyt.gob.ar/noticias/nuevo-sitio-del-sistemade-informacion-de-ciencia-y-tecnologia-argentino-11530 (in Spanish)

[11] Sistema de Informacion de Ciencia y Tecnologia Argentino - EcuRed, available at: https://www.ecured.cu/Sistema_de_Información de_Ciencia_y_Tecnología_ArgentiNo (in Spanish)

[12] Guia de usuario de SICA2, available at: https://sica2.cica.es /help/index.html?anexo_iii.htm (in Spanish)

[13] F. M. Solis Cabrera, "El sistema de informacion cientifica de Andalucia, una experiencia pionera en Espana", Madri+d, No. 22, pp. 12-18, 2008 (in Spanish)

[14] Sistema de Informacion Cientifica de Andalucia, available at: https://sica2.cica.es/\#

[15] P. Desfray, G. Raymond, "Models for Phase C: Information System Architecture", in: Modeling Enterprise Architecture with TOGAF, Morgan Kaufmann, 2009

[16] AMUE, "Gestion de la Recherche, Application des Activit Gestion de la Recherche, Application des Activit es Laboratoires Laboratoires”, 2007 (in French)

[17] A. Bollini, M. Mennielli, S. Mornati, D. T. Palmer, "IRIS: Supporting \& Managing the Research Life-cycle", Universal Journal of Educational Research, Vol. 4, No. 4, pp. 738-743, 2016

[18] V. Zwass, Management Information Systems, Wm. C. Brown, 1992

[19] CINECA Interuniversity Consortium, IRIS, Institutional Research Information System, CINECA, 2015

[20] Universita, Degli Studi di Messina, IRIS (Institutional Research Information System), available at: http://www.unime.it/it/ricerca/irisinstitutional-research-information-system

[21] L. Dempsey, "Research information management systems - a new service category", available at: http://orweblog.oclc.org/researchinformation-management-systems-a-new-service-category/, 2014

[22] ACRL, "Keeping Up With... Research Information Management Systems", available at: http://www.ala.org/acrl/publications/ keeping_up_with/rims, 2016

[23] M. Hasan, N. Maarop, G. N. Samy, H. I. Baharum, W. Z. Abidin, N. H. Hassan, "Developing a success model of Research Information Management System for research affiliated institutions", 2017 International Conference on Research and Innovation in Information Systems (ICRIIS), Langkawi, Malaysia, August 10, 2017

[24] M. Mangena, "Launch of Research Information Management System Project", available at: http://www.polity.org.za/article/sa-mangenalaunch-of-research-information-management-system-project-260220082008-02-26, 2008

[25] University of Newcastle, Australia, "About RIMS", available at: https://www.newcastle.edu.au/research-and-innovation/resources/ research-systems/research-information-management-system-rims/ about-RIMS 
[26] K. Benmoussa, M. Laaziri, S. Khoulji, M. Kerkeb, "SIMARECH 3: A New Application for the Governance of Scientific Research", Transactions on Machine Learning and Artificial Intelligence, Vol. 5, No. 4, 2017

[27] K. Benmoussa, M. Laaziri, S. Khoulji, M. Kerkeb, "Comparative Study of Governance Information Systems for Scientific Research", Transactions on Machine Learning and Artificial Intelligence, Vol. 5, No. 4, pp. 768-775, 2017

[28] D. Coleman, Object-oriented Development: The Fusion Method, Prentice Hall, 1994

[29] M. J. Chonoles, T. Quatrani, Succeeding with the Booch and OMT Methods a Practical Approach, Addison-Wesley, 1996

[30] Software Development Group, "Yourdon Systems Method (YSM)", in: Software Systems Design Methods, pp. 85-110, Liverpool John Moores University, 1999

[31] K. W. Derr, Applying OMT: A Practical Step-by-Step Guide to Using the Object Modeling Technique, SIGS, 1995

[32] B. A. Haugh, M. C. Frame, K. A. Jordan, Object-Oriented Development Process for Department of Defense Information Systems, Institutr for Defence Analyses 1995

[33] J. D. McGregor, T. D. Korson, "Integrated object-oriented testing and development processes", Communications of the ACM, Vol. 37, No. 9, pp. $59-77,1994$

[34] P. Beynon-Davies, "Entity models to object models: object-oriented analysis and database design", Information and Software Technology, Vol. 34, No. 4, pp. 255-262, 1992

[35] H. R. Hiremath, M. J. Skibniewski, "Object-oriented modeling of construction processes by unified modeling language", Automation in Construnction, Vol. 13, No. 4, pp. 447-468, 2004

[36] G. Booch, J. Rumbaugh, I. Jacobson, The Unified Modeling Language User Guide, Addison-Wesley, 1998

[37] M. Kolp, J. Mylopoulos, "Architectural styles for information systems: an organizational perspective", 13th International Conference on Advanced Information Systems Engineering (CAiSE'01), Interlaken, Switzerland, 2001

[38] P. Desfray, G. Raymond, "Models for Phase B", in: Modeling Enterprise Architecture with TOGAF, Morgan Kaufmann, 2009

[39] Symfony, Symfony 4.0 Documentation, available at: https://symfony. $\mathrm{com} / \mathrm{doc} / \mathrm{current} /$ index.html

[40] SIMARech 3, available at: http://simarech.uae.ac.ma/ 